See discussions, stats, and author profiles for this publication at: https://www.researchgate.net/publication/329156547

\title{
Application of multiplex quantitative Polymerase chain reaction methods to detect common bacterial fish pathogens in Nile tilapia, Oreochromis niloticus, hatcheries in Costa Rica
}

Article in Journal of the World Aquaculture Society · November 2018

DOI: $10.1111 /$ jwas. 12576

CITATION

1

9 authors, including:

Adrián López-Porras

Mississippi State University

6 PUBLICATIONS 14 CITATIONS

SEE PROFILE

Alvin Camus

University of Georgia

126 PUBLICATIONS 1,320 CITATIONS

SEE PROFILE

Some of the authors of this publication are also working on these related projects:
READS

272

Aida J Chaves

National University of Costa Rica 16 PUBLICATIONS 196 CITATIONS

SEE PROFILE

Project Flavobacteria in salmonid fish in California View project

Project Genetic diversity of Cyprinid Herpesvirus 3 from different geographical locations in the United States of America View project 


\title{
Application of multiplex quantitative Polymerase chain reaction methods to detect common bacterial fish pathogens in Nile tilapia, Oreochromis niloticus, hatcheries in Costa Rica
}

\author{
Adrián López-Porras $^{1}$ | Carolina Elizondo ${ }^{2}$ | Aida J. Chaves ${ }^{3}$ | \\ Alvin C. Camus ${ }^{4}$ | Matt J. Griffin ${ }^{5}$ (1) | Kirsten Kenelty ${ }^{7}$ | \\ Samantha Barum ${ }^{7}$ | Elías Barquero-Calvo ${ }^{6}$ | Esteban Soto ${ }^{7}$
}

\footnotetext{
${ }^{1}$ Escuela de Medicina Veterinaria, Universidad Nacional de Costa Rica, Heredia, Costa Rica

${ }^{2}$ Programa de Sanidad Acuícola, Servicio Nacional de Salud Animal, Ministerio de Agricultura y Ganaderia, Heredia, Costa Rica

${ }^{3}$ Laboratorio de Patologia Aviar, Escuela de Medicina Veterinaria, Universidad Nacional, Heredia, Costa Rica

${ }^{4}$ Department of Pathology, College of Veterinary Medicine, University of Georgia, Athens, Georgia

${ }^{5}$ Department of Pathobiology and Population Medicine, College of Veterinary Medicine, Mississippi State University, Stoneville, Mississippi

${ }^{6}$ Programa de Investigación en Enfermedades Tropicales, Escuela de Medicina Veterinaria, Universidad Nacional, Heredia, Costa Rica

${ }^{7}$ Department of Epidemiology and Medicine, Davis-School of Veterinary Medicine, University of California, Davis, California

Correspondence

Department of Epidemiology and Medicine, Davis-School of Veterinary Medicine, University of California, Davis, CA. Email: sotomartinez@ucdavis.edu
}

Edwardsiella spp., Streptococcus spp., and Francisella noatunensis subsp. orientalis are some of the most important fish pathogens affecting global tilapia, Oreochromis spp., aquaculture. In Costa Rica, the aquaculture industry is dominated by freshwater-cultured Nile tilapia, Oreochromis niloticus, which are raised in all seven national provinces. At present, little is known regarding the diversity of pathogens present in these facilities, and definitive identification of agents associated with disease outbreaks are rare. To evaluate the prevalence of common bacterial pathogens in these systems, this study used multiplex quantitative polymerase chain reaction (qPCR) assays targeting Edwardsiella, Streptococcus, and Francisella species as a diagnostic and surveillance tool. In 2017, seven different tilapia hatcheries were visited, and 350 fingerlings were subjected to necropsy and molecular diagnostic evaluation. Fish exhibiting gross signs of disease were subjected to histological and microbiological analysis. For the first time, Edwardsiella anguillarum was recovered and molecularly confirmed from diseased tilapia in Costa Rica. In addition, $F$. noatunensis subsp. orientalis was identified in a region of Costa Rica where it had not been previously reported.

KEYWORDS

Costa Rica, diagnosis, pathogen, tilapia

\section{1 | INTRODUCTION}

Tilapia, Oreochromis spp., is one of the most extensively cultivated fish worldwide (Food and Agriculture Organization of the United Nations [FAO], 2016; Huicab-Pech, Landeros-Sánchez, Castañeda-Chávez, Lango-Reynoso, \& López- 
Collado, 2016). Global production was valued at $\$ 1.6$ billion in 2000 but rapidly increased to $\$ 10$ billion in 2014 , representing over $4.85 \times 10^{6}$ m.t. of fish (Fitzsimmons, 2015). Latin American countries, including Costa Rica, have made an important contribution to national and international tilapia markets (FAO, 2016; Webster \& Lim, 2006). Despite this, high feed costs and disease-related losses are significant obstacles limiting aquaculture production. Infectious diseases pose some of the greatest threats to profitability and are estimated to cost the industry millions of dollars annually in the form of lost feed days and overt mortality (Krkosek, 2010; Sommerset, Krossøy, Biering, \& Frost, 2005). Streptococcosis, edwardsiellosis, and francisellosis are among the most important bacterial diseases associated with temperate and warm water-cultured fish, particularly tilapia (Agnew \& Barnes, 2007; Figueiredo, Nobrega Netto, Leal, Pereira, \& Mian, 2012; Griffin, Greenway, \& Wise, 2017; Plump \& Hanson, 2011; Soto, Hawke, Fernandez, \& A. Morales, 2009).

Edwardsiella spp. are Gram-negative, rod-shaped bacteria belonging to the family Enterobacteriaceae. Historically, Edwardsiella tarda has been considered an economically important pathogen in finfish and eel aquaculture, including tilapia (Mohanty \& Sahoo, 2007). Recently, it was determined that E. tarda actually represented three discrete genetic taxa (Abayneh, Colquhoun, \& Sørum, 2013; Griffin et al., 2013). E. tarda, as it is currently defined, is genetically consistent with isolates previously deemed nonfish pathogenic E. tarda, which includes the strain (ATCC 15947) from humans (Griffin et al., 2017; Reichley et al., 2017). Isolates designated as fish pathogenic-typical and -atypical E. tarda now represent the newly described species Edwardsiella piscicida and Edwardsiella anguillarum, respectively (Abayneh et al., 2013; Griffin et al., 2017; Reichley et al., 2017; Shao et al., 2015; Yamada \& Wakabayashi, 1999). Archived genetic sequence data have linked current Edwardsiella systematics to historical reports, suggesting that both E. piscicida and E. anguillarum pose significant risks to temperate and warm water fish (Buján et al., 2017; Griffin et al., 2014; Griffin et al., 2017; Reichley et al., 2017). Edwardsiella ictaluri, the etiological agent of enteric septicemia of catfish, is one of the most economically important diseases of cultured channel catfish in the southeastern United States (Hawke \& Khoo, 2004; Hawke, McWhorter, Steigerwalt, \& Brenner, 1981). Although historically considered a problem limited to catfish aquaculture in the United States, E. ictaluri strains have been recovered from disease outbreaks in other economically important fish species across the world (Crumlish, Dung, Turnbull, Ngoc, \& Ferguson, 2002; Geng et al., 2013; Hawke et al., 2013; Hawke \& Khoo, 2004; Phillips, Reichley, Ware, \& Griffin, 2017; Ye, Li, Qiao, \& Li, 2009) including Nile tilapia, Oreochromis niloticus, cultured in Costa Rica (Soto et al., 2012).

Francisella noatunensis subsp. orientalis (Fno) is a fastidious Gram-negative bacterium and the etiological agent of piscine francisellosis in tilapia (Colquhoun \& Duodu, 2011). In recent years, F. noatunensis subspecies have caused disease outbreaks in different fish species from Asia and Europe, as well as North, South, and Central America (Soto et al., 2014). In Costa Rica, Fno has been documented as one of the most important pathogens affecting local tilapia aquaculture (Birkbeck, Feist, \& Verner-Jeffreys, 2011; Sebastião, Pilarski, Kearney, \& Soto, 2017; Soto et al., 2009). In addition, a novel Francisella species, Francisella marina, has been described from diseased spotted rose snapper, Lutjanus guttatus, in mariculture operations off the Pacific coast of Central America. Epidemiological factors related to outbreaks and host range, including tilapia, of the bacterium are not yet known (Soto et al., in press).

Streptococcosis is a septicemic disease caused by Gram-positive members of the family Streptococcaceae (Jantrakajorn, Maisak, \& Wongtavatchai, 2014). Although Streptococcus dysgalactiae, Streptococcus milleri, Streptococcus phocae, Streptococcus parauberis, Streptococcus difficilis, and Streptococcus ictaluri have been associated with disease in cultured fish (Austin \& Austin, 2016), Streptococcus iniae and Streptococcus agalactiae are the predominant streptococcoal fish pathogens affecting tilapia culture (Evans et al., 2002; Hernandez, Figueroa, \& Iregui, 2009; Iregui, Comas, Vasquez, \& Verjan, 2014). Both have been associated with catastrophic mortalities in wild and cultured fish, often resulting in significant economic losses (Shoemaker, $\mathrm{Xu}, \&$ Soto, 2017).

The diagnosis of these fish pathogens has many constraints, including the fastidious nature of some isolates, in addition to inconsistencies in biochemical, serological, and molecular tests. The diagnosis of these pathogens remains a challenge as current techniques can be laborious, time consuming and expensive, often requiring specialized personnel and equipment. Moreover, current techniques can be prone to false negatives because of low sensitivity or false positives attributed to low specificity. Quantitative polymerase chain reaction (qPCR) is a well-known molecular technique that is currently used in many laboratories for the diagnosis of microbial pathogens, including fastidious 
bacteria. The high sensitivity, high specificity, and rapid turnaround time make this technique an attractive alternative to conventional diagnostic modalities (Espy et al., 2006). Given the importance of these pathogens to tilapia aquaculture, the current study investigated the utility of multiplex qPCR methods for the diagnosis of common bacterial pathogens in diseased tilapia and as a surveillance tool in apparently healthy fish collected from tilapia hatcheries in Costa Rica.

\section{2 | MATERIALS AND METHODS}

\subsection{Fish and tissue samples}

Sample collection was carried out from January to May 2017. Seven different Nile tilapia aquaculture farms distributed throughout Costa Rica were sampled (Figure 1). Tilapia fingerlings were reared in a variety of freshwater systems (Table 1). The day of sampling, clinical history, and water quality parameters of the rearing systems were recorded. Fifty animals per farm were analyzed, giving priority to clinically affected fish observed or reported during the visit. Clinically affected fish included those presenting gross lesions, including exophthalmia and skin ulcers, or irregular behavior, including lethargy, anorexia, abnormal swimming, or struggling to maintain neutral buoyancy. Fish were euthanized with an overdose $(175 \mathrm{mg} / \mathrm{L})$ of AQUI-S ${ }^{\circledR}$ (AquaTactics Fish Health \& Vaccines, Kirkland, WA), weighed, and necropsied. Splenic samples were collected aseptically from each animal, and the tissues were pooled ( $20 \mathrm{mg} ; 5$ spleens/pool) in sterile 1.5-mL microcentrifuge tubes containing $95 \%$ ethanol (ETOH) and then stored at $4^{\circ} \mathrm{C}$. Selected tissues (gills, gut, spleen, liver and heart anterior, and posterior kidney) from fish with clinical signs of disease and gross lesions were fixed in $10 \%$ neutral buffered formalin for histological analysis and stained with hematoxylin and eosin (H\&E), Giemsa, and Gram-Twort stains. In addition, spleen and posterior kidney samples from affected fish were inoculated onto Columbia agar plates supplemented with $5 \%$ sheep blood (Becton Dickinson, Sparks, MD). Aerobic cultures were incubated for $48-72 \mathrm{hr}$ at $25^{\circ} \mathrm{C}$. Bacterial colonies from primary isolation agar plates were inoculated on supplemented Columbia agar for purity of culture and stored cryogenically for later molecular identification $\left(-80^{\circ} \mathrm{C}\right)$.

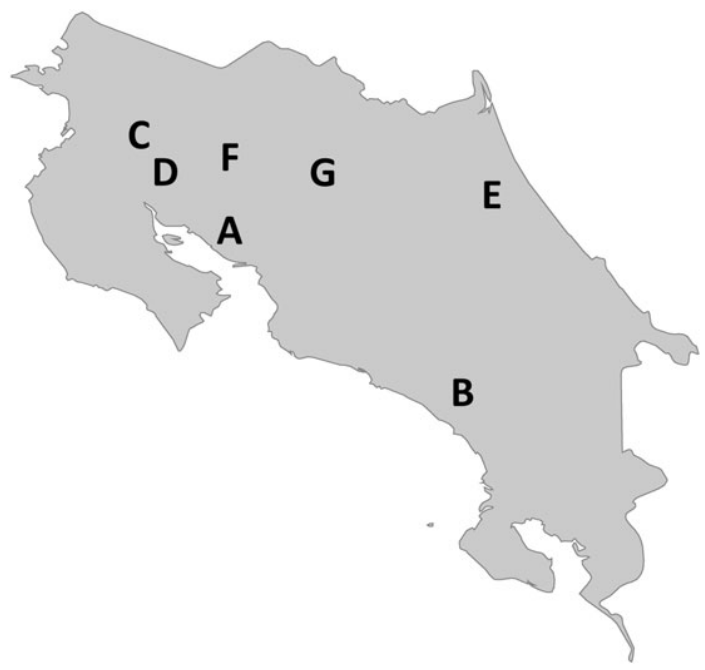

FIGURE 1 Map of Costa Rica indicating the Nile tilapia (Oreochromis niloticus) hatcheries sampled in this study 
TABLE 1 Records summarized from Nile tilapia, Oreochromis niloticus, hatcheries sampled in this study (Figure 1). The total number of hatcheries sampled $(n=7)$ corresponds to those ones that were registered as fingerling producers in the government's national animal health service. The farm naming was performed according to chronological sampling

\begin{tabular}{|c|c|c|c|c|c|}
\hline Farm & $\begin{array}{l}\text { Average weight } \\
\text { (grams) }\end{array}$ & Production system & $\begin{array}{l}\text { Amount of } \\
\text { production }\end{array}$ & $\begin{array}{l}\text { Water temperature }\left({ }^{\circ} \mathrm{C}\right) \\
\text { at collection }\end{array}$ & $\begin{array}{l}\text { Number of } \\
\text { sampled fish }\end{array}$ \\
\hline A & $19.1( \pm 7.6)$ & Recirculating system & 2000 & 28 & 50 \\
\hline B & $32.5( \pm 6.5)$ & $\begin{array}{l}\text { Tanks (fiberglass, } \\
\text { flowthrough) }\end{array}$ & 180,000 & 26 & 50 \\
\hline C & $15( \pm 8.6)$ & $\begin{array}{c}\text { Tanks (concrete, } \\
\text { flowthrough) }\end{array}$ & $1,200,000$ & 27.4 & 50 \\
\hline D & $19.9( \pm 8.1)$ & Earth ponds & 80,000 & 25 & 50 \\
\hline$E$ & $9.6( \pm 4.2)$ & Earth ponds & 125,000 & 28 & 50 \\
\hline $\mathrm{F}$ & $27.8( \pm 10.8)$ & Earth ponds & 20,000 & 26.4 & 50 \\
\hline G & $4.4( \pm 1.3)$ & Earth ponds & 60,000 & 26 & 50 \\
\hline
\end{tabular}

\section{2 | DNA extraction}

Ethanol was removed from spleen pools prior to homogenization in $500 \mu \mathrm{L}$ of phosphate-buffered saline, and homogenized tissue was stored at $-20^{\circ} \mathrm{C}$. Total genomic DNA (gDNA) was isolated using the DNEasy Blood and Tissue Kit (QIAGEN, Germantown, MD) in accordance with the manufacturer's suggested protocol. Isolated gDNA was quantified using a Cytation ${ }^{\mathrm{TM}} 5$ imaging reader and Gen3 software (BioTek, Winooski, VT). Total gDNA from each pool was then adjusted to $10 \mathrm{ng} / \mu \mathrm{L}$ with $\mathrm{AE}$ buffer (QIAGEN).

\subsection{F. noatunensis subsp. orientalis (Fno), S. iniae, and S. agalactiae multiplex qPCR assay}

A multiplex qPCR using minor groove binder probes was designed for three bacterial strains commonly associated with disease outbreaks in cultured tilapia. Primer and probes were designed using Primer Express ${ }^{\mathrm{TM}}$ Software 3.0.1 (Thermo Fisher Scientific, Waltham, MA) targeting the Fno sodB (GenBank accession number CP018051), S. iniae rpoB (GenBank accession number CP017952), and S. agalactiae gyrB genes (GenBank accession number CP003919). Primers and probes (Table 2) were synthesized by Life Technologies (Grand Island, NY).

All three assays were validated in both simplex and multiplex formats using both TaqMan Universal Master Mix (UMM; Thermofisher Scientific, Waltham, MA) and TaqMan Environmental Master Mix v2.0 (EMM; Thermofisher Scientific, Waltham, MA). The 12-ul qPCR simplex and multiplex reactions consisted of $6 \mu \mathrm{L}$ of commercially available PCR Master Mix (UMM or EMM; Thermofisher Scientific, Waltham, MA), 2.5 pmols of each primer, 0.5 pmols of probe, $5 \mu \mathrm{L}$ of gDNA, and nuclease-free water to volume. Reactions were run in a 384 well-plate and amplified in a 7900HT FAST qPCR system (Thermo Fisher Scientific) using the manufacturer's standard amplification conditions $\left(2 \mathrm{~min}\right.$ at $50^{\circ} \mathrm{C}$, $10 \mathrm{~min}$ at $95^{\circ} \mathrm{C}$, then 40 cycles of $15 \mathrm{~s}$ at $95^{\circ} \mathrm{C}$ and $60 \mathrm{~s}$ at $60^{\circ} \mathrm{C}$ ). Fluorescent signals were collected following the anneal/extension step, and the quantification cycle $(\mathrm{Cq})$ was calculated based on a threshold of 0.1 with the baseline fluorescence established from cycles 3 to 12 .

The sensitivity and linear dynamic range of each assay was determined using serial dilutions of known quantities of genomic bacterial DNA isolated from each target organism (DNEasy Blood and Tissue Kit, QIAGEN, Germantown, MD). Each dilution series was run in triplicate on three separate occasions to assess repeatability and reproducibility of the assay (Figure 2). Only gDNA from the target bacteria was added to the reaction in simplex assay validation, whereas gDNA from all three target bacteria were combined in validation of multiplex reactions. To this end, each reaction mixture was supplemented with an equal mixture of $\sim 1 \mathrm{ng}$ of each nontarget bacterial gDNA to ensure that large quantities of nontarget DNA did not impair reaction efficiency (Figure 3). Standard curves were generated for each set of dilutions, and amplification efficiency (E) for all assays was calculated from the slope of the curve using the formula $E=10^{1 /-s}-1$. Samples with a mean $\mathrm{Cq}$ value of $\leq 40$ (with fluorescence in all three wells) were 
TABLE 2 Primers and probes used in multiplex quantitative polymerase chain reactions (qPCRs) for Francisella noatunensis subsp. orientalis (Fno), Streptococcus agalactiae, Streptococcus iniae and the Edwardsiella spp. melting temperature $\left(T_{m}\right)$, amplicon length, amplicon guanine-cytosine content (GC-Content) and Genbank accession number are presented. The Fno, S. agalactiae, and S. iniae multiplex quantitative polymerase chain reaction (mPCR) was developed as part of the current study. Primer and probe sequences for the Edwardsiella spp. mPCR have been obtained from previous work (Bilodeau et al. 2003; Griffin et al. 2011; Reichley, Waldbieser, Lawrence, \& Griffin, 2015,b; Reichley et al., 2017)

\begin{tabular}{|c|c|c|c|c|c|}
\hline Primer/probe & Sequence $\left(5^{\prime}-3^{\prime}\right)$ & $T_{m}$ & $\begin{array}{l}\text { Amplicon } \\
\text { GC\% }\end{array}$ & $\begin{array}{l}\text { Amplicon } \\
\text { length }\end{array}$ & $\begin{array}{l}\text { Accession } \\
\text { number }\end{array}$ \\
\hline \multicolumn{3}{|l|}{ Fno } & 32 & 102 bp & CP018051 \\
\hline Fno-70f & GCTGCTTTCAATTGACTAGAAGGTT & 58.0 & & & \\
\hline Fno-172r & CTGGCGTCATATTTAACAATTCAGC & 58.0 & & & \\
\hline Fno-102p & FAM-ACTTAGAGTTAAACAATTCC-MGB-NFQ & 68.0 & & & \\
\hline \multicolumn{2}{|l|}{ Streptococcus iniae } & & 38 & $103 \mathrm{bp}$ & CP017952 \\
\hline S. iniae $-551 \mathrm{f}$ & GTGTCCGATTGAGACACCAGAG & 58.0 & & & \\
\hline S. iniae- $653 r$ & GCGGTAAGGTGTTTGAATAAAGC & 58.0 & & & \\
\hline S. iniae $-583 p$ & TET-TCGGTCTGATCAATAACTTA-MGB-NFQ & 68.0 & & & \\
\hline \multicolumn{3}{|c|}{ Streptococcus agalactiae } & 39 & $104 \mathrm{bp}$ & CP011328 \\
\hline S. agal-423f & CGGTGAATTAGATGGTATTTCAGTTG & 58.0 & & & \\
\hline S. agal-527r & ССTCCTTCATGAGTGTGGATGTT & 58.0 & & & \\
\hline S. agal-450p & VIC-AGTAGCAATGCAGTATAC-MGB-NFQ & 68.0 & & & \\
\hline \multicolumn{3}{|c|}{ Edwardsiella anguillarum } & 50 & $131 \mathrm{bp}$ & CP011516 \\
\hline EPL1583F & GATCGGGTACGCTGTCAT & 56.9 & & & \\
\hline EPL1708R & AATTGCTCTATACGCACGC & 56.6 & & & \\
\hline EPL1611P & TxRed-CCCGTGGCTAAATAGGACGCG-BHQ2 & 67.8 & & & \\
\hline \multicolumn{3}{|c|}{ Edwardsiella ictaluri } & 53 & $178 \mathrm{bp}$ & NC_012779 \\
\hline El481F & АCTTATCGCCCTCGCAACTC & 61.7 & & & \\
\hline El658R & ССTCTGATAAGTGGTTCTCG & 55.0 & & & \\
\hline El561P & HEX-CCTCACATATTGCTTCAGCGTCGAC-BHQ1 & 68.0 & & & \\
\hline \multicolumn{3}{|c|}{ Edwardsiella piscicida } & 52 & $131 \mathrm{bp}$ & CP016044 \\
\hline EP14529F & CTTTGATCATGGTTGCGGAA & 62.0 & & & \\
\hline EP14659R & CGGCGTTTTCTTTTCTCG & 59.5 & & & \\
\hline EP14615P & FAM-CCGACTCCGCGCAGATAACG-BHQ1 & 68.3 & & & \\
\hline \multicolumn{2}{|c|}{ Edwardsiella tarda } & & 54 & $115 \mathrm{bp}$ & CP011359 \\
\hline ET3518F & CAGTGATAAAAAGGGGTGGA & 57.5 & & & \\
\hline ET3632R & CTACACAGCAACGACAACG & 56.4 & & & \\
\hline ET3559P & Cy5-AGACAACAGAGGACGGATGTGGC-BHQ2 & 67.0 & & & \\
\hline
\end{tabular}

considered positive. Specificity of the assay was evaluated using previously identified bacterial pathogens recovered from aquatic animals (Table 3). These protocols were then used to evaluate gDNA isolated from collected spleen pools.

\subsection{E. tarda, E. piscicida, E. anguillarum, and E. ictaluri multiplex quantitative polymerase chain reaction assay}

As described above, gDNA from all spleen pools were subjected to a multiplex real-time PCR assay targeting the four Edwardsiella spp. known to infect fish (Reichley et al., 2017). Each sample was run in triplicate on a C1000 Touch ${ }^{\mathrm{TM}}$ thermal cycler equipped with a CFX96 ${ }^{\mathrm{TM}}$ optical reaction module (BioRad, Hercules, CA) and analyzed using the End Point utility of the CFX ManagerTM version 3.1 software (End Cycles to Average: 5; Percent of Range: 10.0, BioRad, 
(a)

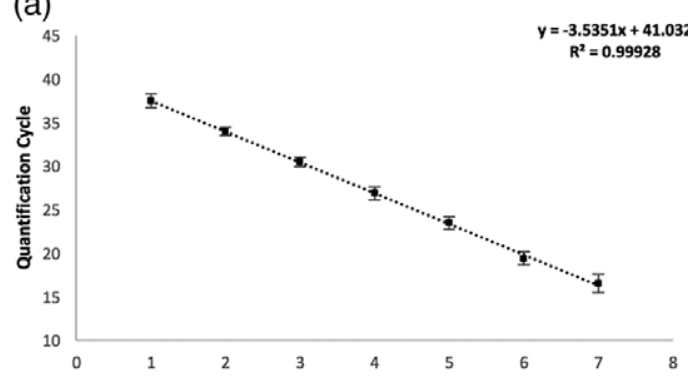

(c)

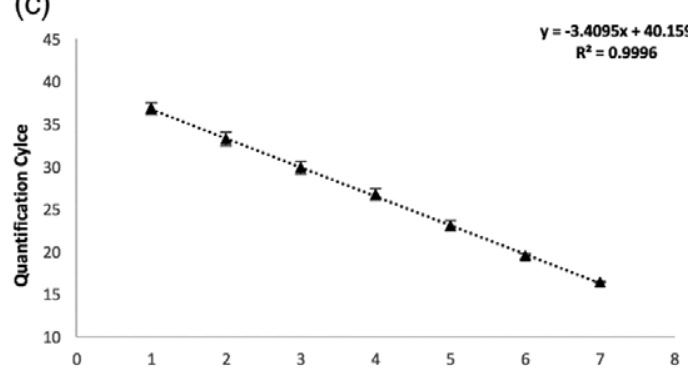

(e)

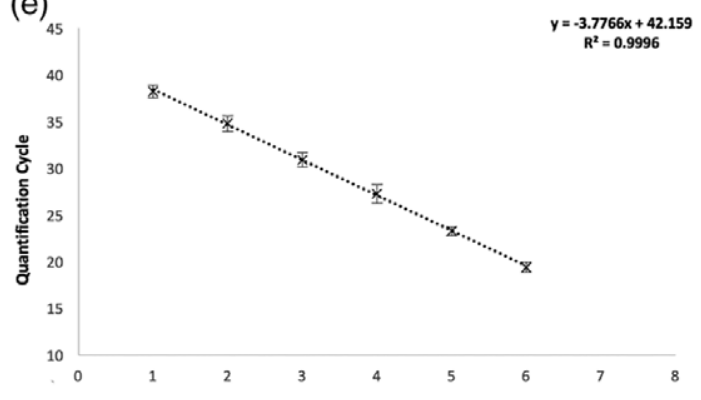

(b)

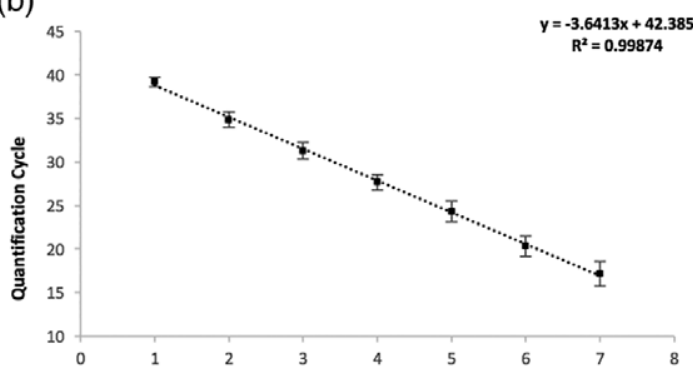

(d)

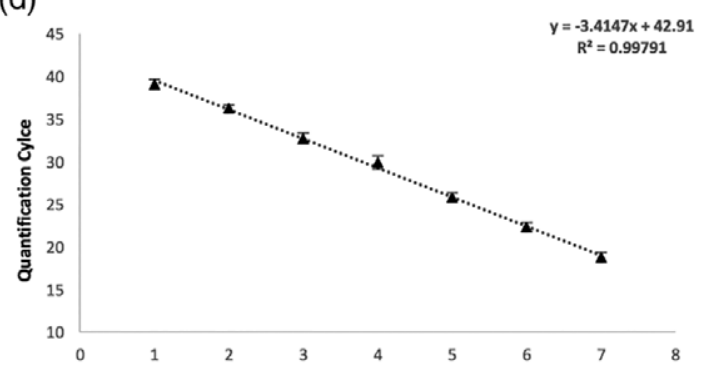

(f)

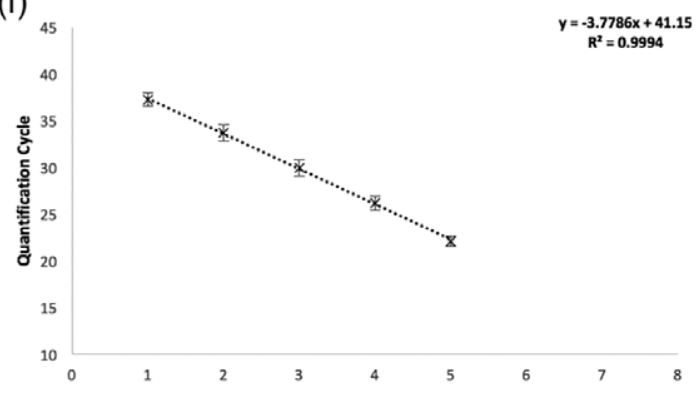

\section{LOG 10 Genome Equivalents}

FIGURE 2 Mean quantification cycles for known quantities of Francisella noatunensis subsp. orientalis (Fno) (a, b), Streptococcus iniae (c, d), Streptococcus agalactiae (e, f) target DNA using universal (a, c, e) or environmental master mix (b, d, f) (applied biosystems). A 10-fold dilution series of quantified bacterial DNA was analyzed for each assay. Error bars indicate $S D$ s generated from samples ran in triplicate on three separate plates. Reaction efficiencies for each assay were calculated from the slope of the log-linear portion of concurrently run standards (PCR efficiency $\left.=10^{1 /-s}-1\right)$. PCR, polymerase chain reaction

Hercules, CA). Primers and probes were synthesized commercially (Eurofins MWG; Louisville, KY). Each probe was labeled with a fluorescent reporter dye (E. anguillarum, Texas Red; E. ictaluri, 5-HEX; E. piscicida, 6-FAM; E. tarda, Cy5) on the $5^{\prime}$ end and with appropriate quencher dye (black hole quencher-1 for HEX and 6-FAM; black hole quencher-2 for Texas Red and Cy5) on the $3^{\prime}$ end. Primer and probe sequences are provided in Table 2.

The $25-\mu \mathrm{L}$ reaction contained $12 \mu \mathrm{L}$ of PCR master mix (TaqMan Environmental Mastermix 2.0, Applied Biosytems, Foster City, CA), 5 pmols of each primer, 0.5 pmols of each probe, $5 \mu \mathrm{L}$ of gDNA (10 ng/ $\mu \mathrm{L}$ ) template, and nuclease-free water to volume. Amplifications were performed with the following temperature profile: 1 cycle of $95^{\circ} \mathrm{C}$ for $15 \mathrm{~min}$ followed by 40 cycles of $95^{\circ} \mathrm{C}$ for $15 \mathrm{~s}$ and $60^{\circ} \mathrm{C}$ for $1 \mathrm{~min}$. Data collection occurred following the $60^{\circ} \mathrm{C}$ annealing/extension step at the end of each cycle. Genomic DNA isolated from the spleen of naive blue $(n=2)$ 

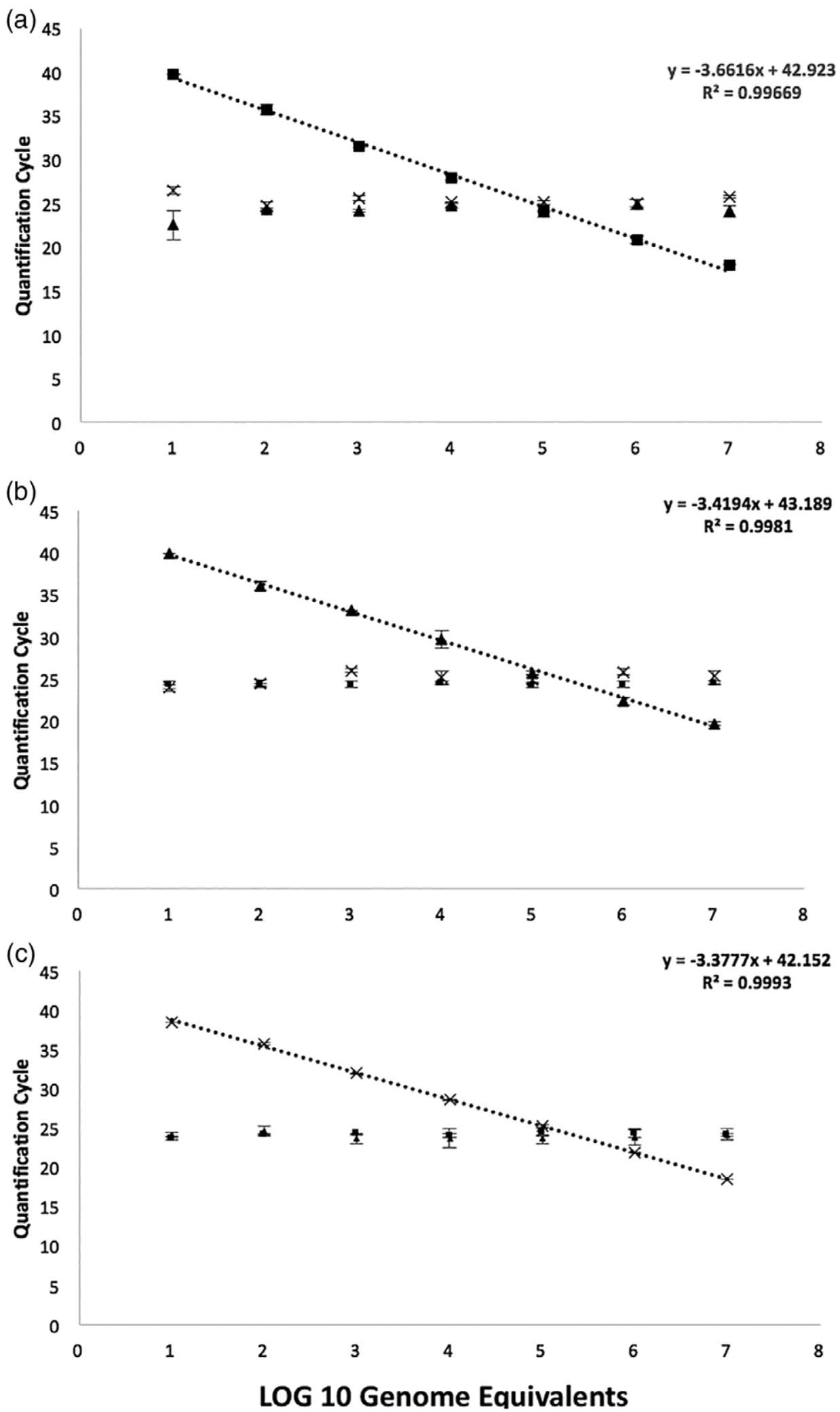

FIGURE 3 Legend on next page. 
and Nile $(n=2)$ tilapia was analyzed concurrently, with all samples serving as true negative controls. Positive controls consisting of an equimolar pool of E. anguillarum LADL 05-105 (Griffin et al., 2014; Reichley, Waldbieser, Lawrence, \& Griffin, 2015), E. ictaluri S97-773 (Griffin et al., 2014), E. piscicida S11-285 (Griffin et al., 2014; Reichley, Waldbieser, Tekedar, Lawrence, \& Griffin, 2016), and E. tarda (Griffin et al., 2014; Reichley, Waldbieser, Tekedar, Lawrence, \& Griffin, 2015) gDNA, as well as no template controls, were included with each plate.

\subsection{Results}

Regardless of the PCR supermix used, the newly designed multiplex qPCR assay targeting Fno, S. iniae, and S. agalactiae was found to be repeatable and reproducible, with a linear dynamic range covering at least five orders of magnitude. Based on estimated genome sizes of $1.9 \mathrm{Mb}$ for Fno (Figueiredo et al., 2016), $2 \mathrm{Mb}$ for S. iniae (Gong et al., 2017), and $2 \mathrm{Mb}$ for S. agalactiae (Mainardi et al., 2016), the limit of sensitivity for each assay was approximately 20, 8, and 20 genome equivalents, respectively. Each assay was specific to its respective target, with no evidence of cross-reactivity from nontarget organisms (Figure 3; Table 3).

Sample collection occurred from January to May, a period of volatile weather patterns, seasonal changes, and the transition from the dry to rainy season. This is also the period when disease outbreaks typically occur in Costa Rica. Sampling occurred on the seven largest Nile tilapia aquaculture farms in Costa Rica, all of which possessed onsite hatcheries. Farms A, D, E, F, and G did not report any disease-related mortality before or at the time of the site visit, and no pathogenic bacteria were detected by qPCR in spleen pools collected from these operations (Table 4). Farm B had experienced 30-40\% mortality in affected systems 6 weeks prior to the visit. Water temperature at the time of sampling ranged from 24 to $26^{\circ} \mathrm{C}$. Gross pathological findings in this group were typical of piscine francisellosis, including splenomegaly, renomegaly, and visceral adhesions. White nodules, corresponding microscopically to granulomas and foci of necrosis, were variably present in the spleen, kidney, liver, myocardium, pericardium, and gills. Histologically, multifocal, variably sized granulomas composed of central areas of necrosis surrounded by mantles of epithelioid macrophages were consistently observed. Vacuolated macrophages, containing small pleomorphic coccobacilli and scattered lymphocytes, were present on the periphery (Figure 4a). More chronic cases were characterized by granulomas containing larger areas of free and phagocytized necrotic debris, but there were no identifiable bacteria in H\&E- or Giemsa-stained sections. Extensive fibroplasia was associated with some locations, such as the pericardial cavity. All 10 spleen pools recovered from this hatchery were positive for Fno (32.85 \pm 1.7$)$, while the qPCR was negative for Streptococcus spp. and Edwardsiella spp. No bacteria were cultured on Columbia blood agar from any of the sampled fish. However, special media, such as Thayer Martin, are required for the isolation of Fno.

Farm C was experiencing low mortalities (6-8\%) during the visit at which time water temperatures ranged from 26 to $29^{\circ} \mathrm{C}$. Diseased fish were lethargic, externally darkened, and swimming erratically. Necropsy demonstrated bilateral exophthalmia, hepatomegaly, splenomegaly, and renomegaly. Again, white nodules consistent with foci of necrosis and granulomas were widespread in kidneys and spleens. Microscopic lesions varied from small foci of parenchymal coagulative necrosis and hemorrhage to organized granulomas, both containing variable numbers of free and phagocytized bacterial rods. Necrotic foci were frequently surrounded by mixed mononuclear inflammatory infiltrates, while granulomas had large hypereosinophilic cores of cellular debris surrounded by epithelioid macrophages and, often, a capsule of fibrous connective tissue (Figure 4b). Multifocal basophilic mineral deposits, consistent with mild nephrocalcinosis, were present in the renal interstitium and tubular lumens of some fish. No significant

FIGURE 3 Mean quantification cycles for serial 10-fold dilutions of known quantities of Francisella noatunensis subsp. orientalis (Fno) (a), Streptococcus iniae (b), Streptococcus agalactiae (c) target DNA using environmental master mix (applied biosystems). A dilution series for each assay was performed in the presence of an equal mixture of $\sim 1 \mathrm{ng}$ of each nontarget bacterial gDNA. Error bars indicate SDs generated from samples run in triplicate on three separate plates. Reaction efficiencies for each assay were calculated from the slope of the log-linear portion of concurrently run standards (PCR efficiency $\left.=10^{1 /-s}-1\right)$. $P C R$, polymerase chain reaction 
TABLE 3 Isolates used in this study to validate the Francisella noatunensis subsp. orientalis (Fno), Streptococcus iniae, and Streptococcus agalactiae qPCR assay

\begin{tabular}{|c|c|c|c|c|}
\hline Isolate & Year of isolation & Location & Fish & Reference \\
\hline Fno 1 & 2001 & Japan & Three line grunt & Kamaishi et al., 2005 \\
\hline Fno 2 & 2011 & Texas, United States & Tilapia & Unpublished \\
\hline Fno 3 & 2012 & Costa Rica & Nile tilapia & Unpublished \\
\hline Fno 4 & 2012 & Hawaii, United States & Tilapia & $\begin{array}{l}\text { Soto, McGovern-Hopkins, } \\
\text { et al., } 2013\end{array}$ \\
\hline Fno 5 & 2013 & Florida, United States & French grunt & Soto et al., 2014 \\
\hline S. iniae & 1994 & IL, United States & Tilapia & Chou et al. 2014 \\
\hline S. iniae & 1994 & MA, United States & Hybrid striped bass & Chou et al. 2014 \\
\hline S. iniae & 2015 & CA, United States & Mossambique tilapia & Soto et al. 2017 \\
\hline S. iniae & 2015 & CA, United States & White sturgeon & Soto et al. 2017 \\
\hline S. iniae & 2015 & CA, United States & White sturgeon & Soto et al. 2017 \\
\hline S. iniae & 2001 & MN, United States & Nile tilapia & Chou et al. 2014 \\
\hline S. iniae & 2003 & FL, United States & Albino rainbow shark & Chou et al. 2014 \\
\hline S. iniae & 1999 & Southern Caribbean & Reef fish & Ferguson et al. 2000 \\
\hline S. iniae & 2008 & West Indies & Reef fish & Keirstead et al. 2014 \\
\hline S. agalactiae & 2015 & Costa Rica & Nile tilapia & Soto et al. 2016 \\
\hline S. agalactiae & 2005 & Honduras & Tilapia & Soto et al. 2015 \\
\hline S. agalactiae & 2009 & CA, United States & Tilapia & Unpublished \\
\hline S. agalactiae & 2009 & CA, United States & Tilapia & Unpublished \\
\hline S. agalactiae & 2009 & CA, United States & Tilapia & Unpublished \\
\hline S. agalactiae & 2009 & CA, United States & Tilapia & Unpublished \\
\hline S. agalactiae & 2009 & CA, United States & Tilapia & Unpublished \\
\hline S. agalactiae & 2017 & CA, United States & Tilapia & Unpublished \\
\hline S. agalactiae & 2017 & CA, United States & Tilapia & Unpublished \\
\hline S. agalactiae & 2017 & CA, United States & Tilapia & Unpublished \\
\hline S. agalactiae & 2017 & CA, United States & Tilapia & Unpublished \\
\hline $\begin{array}{l}\text { Flavobacterium } \\
\text { columnare }\end{array}$ & 2017 & CA, United States & Rainbow trout & Unpublished \\
\hline Flavobacterium psychrophilum & 2017 & CA, United States & Rainbow trout & Unpublished \\
\hline Mycobacterium marinum & 2017 & CA, United States & Zebrafish & Unpublished \\
\hline Mycobacterium chelonae & 2017 & CA, United States & Zebrafish & Unpublished \\
\hline Mycobacterium abbsecuss & 2017 & CA, United States & Zebrafish & Unpublished \\
\hline Nocardia sp. & 2017 & CA, United States & Marine mammal & Unpublished \\
\hline Edwardsiella ictaluri & 2012 & Costa Rica & Tilapia & Unpublished \\
\hline Edwardsiella anguillarum & 2017 & Costa Rica & Tilapia & Current study \\
\hline Aeromonas sp. & 2017 & CA, United States & Tilapia & Unpublished \\
\hline Aeromonas sp. & 2017 & CA, United States & Koi & Unpublished \\
\hline Aeromonas sp. & 2017 & CA, United States & Tilapia & Unpublished \\
\hline
\end{tabular}

changes were present in the gastrointestinal tract, liver, heart, or brain. Six spleen pool samples from this hatchery were qPCR positive for E. anguillarum, while the qPCR was negative for all other pathogens tested (Table 4). Two pure bacterial isolates, morphologically consistent with an Edwardsiella spp., were obtained from affected fingerlings and later molecularly confirmed as E. anguillarum based on previously established methods (Griffin et al., 2014; Reichley et al., 2017). 
TABLE 4 Molecular diagnosis of Francisella noatunensis subsp. orientalis (Fno), Streptococcus iniae, Streptococcus agalactiae, Edwardsiella tarda, Edwardsiella piscicida, Edwardsiella anguillarum, and Edwardsiella ictaluri using multiplex quantitative polymerase chain reaction (qPCR). Seven Nile tilapia hatcheries were sampled. Fifty splenic samples were collected from each farm and subjected to molecular diagnosis. Ten pools ( $n=5$ animals) per farm were analyzed

\begin{tabular}{|c|c|c|c|c|c|c|c|}
\hline Hatchery & Fno & E. anguillarum & E. tarda & E. piscicida & E. ictaluri & S. agalactiae & S. iniae \\
\hline$A$ & - & - & - & - & - & - & - \\
\hline B & $(10 / 10)^{+}$ & - & - & - & - & - & - \\
\hline C & - & $(6 / 10)^{+}$ & - & - & - & - & - \\
\hline D & - & - & - & - & - & - & - \\
\hline$E$ & - & - & - & - & - & - & - \\
\hline $\mathrm{F}$ & - & - & - & - & - & - & - \\
\hline G & - & - & - & - & - & - & - \\
\hline
\end{tabular}

${ }^{+}$Positive pools per farm.

\section{DISCUSSION}

Disease impacts on aquaculture production extend beyond direct losses associated with mortality. Disease also results in arrested production and growth, additional labor and energy costs, and increased treatment expenditures. Furthermore, the release of pathogens into the environment poses a potential risk to wild fish populations and humans. Delays in diagnosis and the initiation of antimicrobial treatment in response to bacterial pathogens can result in therapeutic failures, especially with the use of medicated feeds, as inappetence often increases as an outbreak progresses in a population (Reimschuessel, Miller, \& Gieseker, 2013). As a result, rapid diagnostics play a key role in health management and improved production efficiencies in aquaculture.

In the current project, a novel molecular assay demonstrated the presence of Fno DNA in southeast Costa Rica (farm B), the first report of the pathogen in this region. Although no mortalities were occurring in the hatchery at the time of sampling, fingerlings from the farm exhibited internal gross and histopathological lesions consistent with piscine francisellosis (Colquhoun \& Duodu, 2011; Soto et al., 2013; Soto et al., 2013), and Fno DNA was confirmed in all samples. A mortality event 6 weeks earlier had gone undiagnosed following the introduction of broodstock from regions where Fno is endemic. According to Peeler and Taylor (2011), the movement of fish between hatcheries poses a high-risk factor for the dissemination of bacterial pathogens to previously unaffected farms and/or new geographical areas. This is particularly important with diseases such as francisellosis, where the role of asymptomatic carriers in disease transmission is not well established. This case highlights the need for best management practices, including pathogen surveillance, implementation of biosecurity protocols, and the purchase of certified pathogen-free stock to prevent or minimize the introduction of disease agents into hatcheries and farms and to limit their spread on production operations (Wise, Camus, Schwedler, \& Terhune, 2004; Plump \& Hanson, 2011).

This is also the first report of the recently described E. anguillarum (Shao et al., 2015) affecting tilapia culture in Costa Rica. It is unknown whether this finding indicates a newly emerging pathogen in Costa Rica or if the organism has been present but has gone previously undiagnosed or misdiagnosed given that the lesions are similar to those of Fno and E. ictaluri infections in tilapia (Soto et al., 2009; Soto et al., 2012). While E. ictaluri is common on catfish operations in the United States, causing annual outbreaks at permissible temperatures (Hawke \& Khoo, 2004; Klesius, 1992), similar information regarding $E$. anguillarum is not yet available. Further studies focusing on phylogenetics, virulence, and antimicrobial susceptibility are needed to gain a better understanding of $E$. anguillarum and its potential role in disease outbreaks in tilapia aquaculture in Central America.

No other Edwardsiella spp. were identified in this study. Furthermore, neither S. agalactiae nor S. iniae were detected in any of the spleen pools submitted for molecular analysis. However, previous reports have shown that Streptococcus spp. are endemic to Costa Rican tilapia farms, particularly in operations where water temperatures 


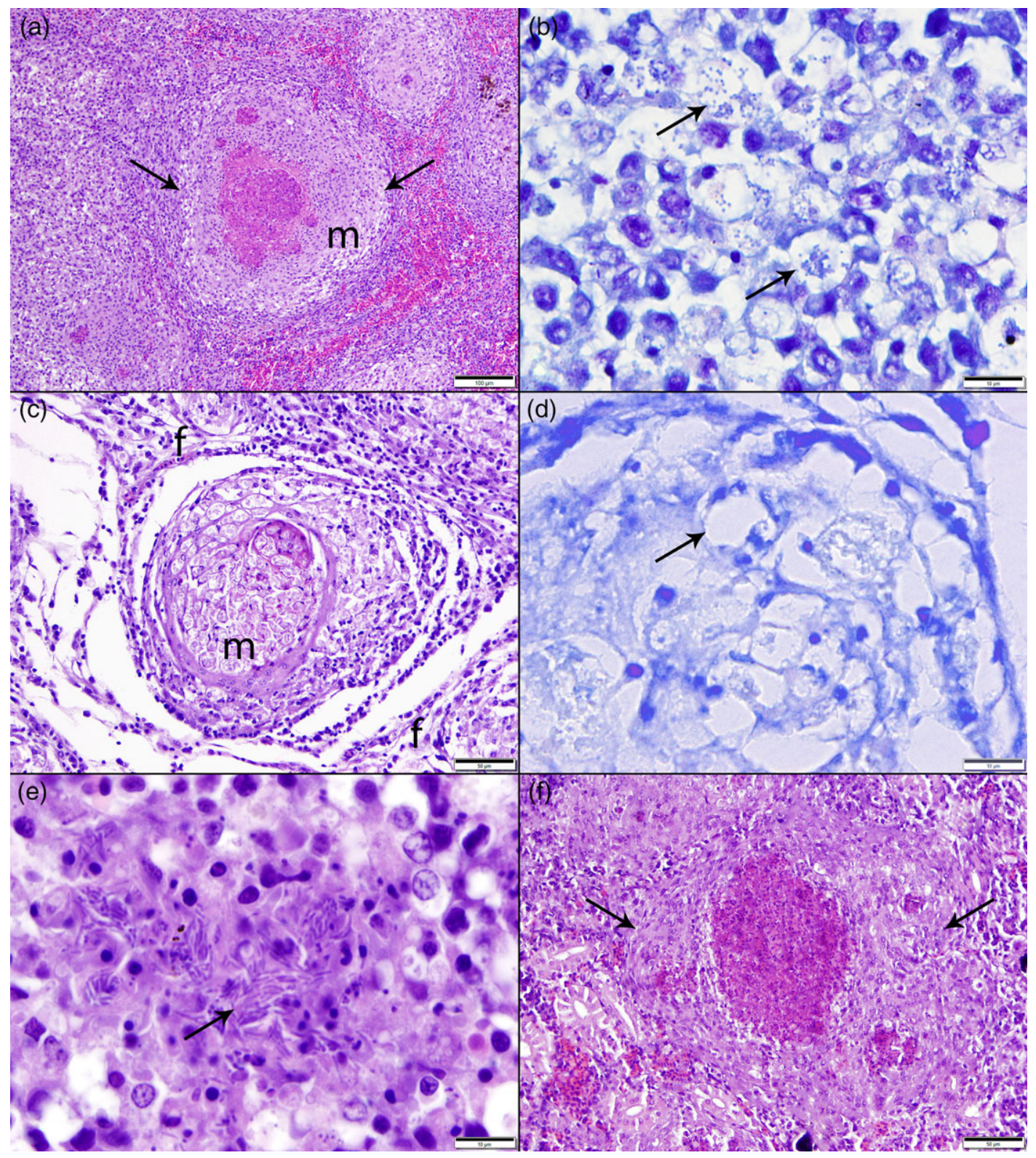

FIGURE 4 Francisella noatunensis subsp. orientalis (Fno) and Edwardsiella anguillarum lesions in Nile tilapia fingerlings.

(a) Early granuloma development (arrows) in head kidney of a tilapia experimentally challenged with Fno. There is central necrosis surrounded by a zone of epithelioid macrophages, many with cytoplasmic vacuoles (H\&E stain, bar $=100 \mu \mathrm{m}$ ). (b) During the early stages of infection, coccoid bacteria (arrows) typical of Fno are present within cytoplasmic vacuoles of macrophages (Giemsa stain, bar $=10 \mu \mathrm{m}$ ). (c) Nile tilapia from a Costa Rican hatchery chronically infected with Fno. A granuloma in the pericardial cavity is surrounded by fibroplasia ( $f$ ) and scattered lymphocytes. A thin wall of epithelioid cells envelops a large central region of vacuolated macrophages $(\mathrm{m})$ laden with granular cell debris (H\&E stain, bar $=50 \mu \mathrm{m}$ ). (d) In these chronic lesions, bacteria could not be visualized in vacuoles (arrow) despite positive PCR results (Giemsa stain, bar $=10 \mu \mathrm{m}$ ). (e) E. anguillarum bacterial rods (arrow) within an area of necrosis in a naturally infected tilapia from Brazil (H\&E stain, bar $=10 \mu \mathrm{m}$ ). (e) Granuloma formation in a tilapia from Costa Rica. In the absence of bacteria, the granuloma (arrows) cannot be readily distinguished from that induced by Fno in (a) above (H\&E stain, bar $=50 \mu \mathrm{m})$. PCR, polymerase chain reaction 
exceed $30^{\circ} \mathrm{C}$ (Barquero-Calvo, unpublished data). Further studies are necessary on the impacts of streptococcosis on tilapia hatcheries in Costa Rica.

Although this study was limited in scope, it demonstrates the value of using molecular techniques to obtain accurate diagnostic results in hatchery situations, both among symptomatic and asymptomatic populations of fish. This is particularly evident with diseases such as francisellosis and edwardsiellosis that produce similar gross and microscopic lesions. While the two conditions are readily differentiated microscopically when bacteria can be visualized, small coccoid bacteria versus rods, respectively, with chronicity bacterial numbers can be low, complicating histological interpretation (Soto, Kidd, et al., 2013). Molecular-based methods also circumvent diagnostic failures resulting from a lack of specialized media to culture more fastidious organisms, such as Fno. The methods developed and results obtained are applicable to the design of future surveillance programs for fish diseases, decreasing the chances of disseminating bacterial pathogens between hatcheries, farms, and the environment. Furthermore, this study highlights the crucial need for the establishment of a national disease surveillance program to prevent the introduction of disease agents, as well as limit their impacts and spread on Costa Rican aquaculture facilities.

\section{ORCID}

Matt J. Griffin (DD https://orcid.org/0000-0002-7920-3446

Esteban Soto (iD) https://orcid.org/0000-0001-6054-9634

\section{REFERENCES}

Abayneh, T., Colquhoun, D. J., \& Sørum, H. (2013). Edwardsiella piscicida sp. nov. a novel species pathogenic to fish. Journal of Applied Microbiology, 114(3), 644-654.

Agnew, W., \& Barnes, A. (2007). Streptococcus iniae: An aquatic pathogen of global veterinary significance and a challenging candidate for reliable vaccination. Veterinary Microbiology, 122, 1-15.

Austin, B., \& Austin, D. A. (2016). Bacterial fish pathogens: Diseases of farmed and wild fish (6th ed., pp. 34-67). Basel, Switzerland: Springer International.

Bilodeau, A. L., Waldbieser, G. C., Therhune, J. S., Wise, D. J., \& Wolters, W. R. (2003). A Real-Time Polymerase Chain Reaction Assay of the Bacterium Edwardsiella ictaluri in Channel Catfish. Journal of Aquatic Animal Health, 15, 80-86.

Birkbeck, T. H., Feist, S. W., \& Verner-Jeffreys, D. W. (2011). Francisella infections in fish and shellfish. Journal of Fish Diseases, 34, 173-187.

Buján, N., Mohammed, H., Balboa, S., Romalde, J. L., Toranzo, A. E., Arias, C. R., \& Magariños, B. (2017). Genetic studies to re-affiliate Edwardsiella tarda fish isolates to Edwardsiella piscicida and Edwardsiella anguillarum species. Systematic and Applied Microbiology, 41, 30-37.

Chou, L., Griffin, M. J., Fraites, T., Ware, C., Ferguson, H., Keirstead, N., ... Soto, E. (2014). Phenotypic and genotypic heterogeneity among Streptococcus iniae isolates recovered from cultured and wild fish in North America, Central America and the Caribbean islands. Journal of Aquatic Animal Health, 26, 263-271.

Colquhoun, D. J., \& Duodu, S. (2011). Francisella infections in farmed and wild aquatic organisms. Veterinary Research, 42, 47-63.

Crumlish, M., Dung, T. T., Turnbull, J. F., Ngoc, N. T. N., \& Ferguson, H. W. (2002). Identification of Edwardsiella ictaluri from diseased freshwater catfish, Pangasius hypophthalmus (Sauvage), cultured in the Mekong Delta, Vietnam. Journal of Fish Diseases, 25, 733-736.

Espy, M. J., Uhl, J. R., Sloan, L. M., Buckwalter, S. P., Jones, M. F., Vetter, E. A., ... Smith, T. F. (2006). Real-time PCR in clinical microbiology: Applications for routine laboratory testing. Clinical Microbiology Reviews, 19, 165-256.

Evans, J. J., Klesius, P. H., Gilbert, P. M., Shoemaker, C. A., Al-Sarawi, M. A., Landsberg, J., ... Al Kenzi, S. (2002). Characterization of B-haemolytic group B Streptococcus agalactiae in cultured seabream, Sparus auratus L., and wild mullet, Liza klunzingeri (day), in Kuwait. Journal of Fish Diseases, 25, 505-513.

Ferguson, H. W., St John, V. S., Roach, C. J., Willoughby, S., Parker, C., \& Ryan, R. (2000). Caribbean reef fish mortality associated with Streptococcus iniae. Veterinary Research, 147, 662-664.

Figueiredo, H. C., Leal, C. A., Pereira, F. L., Soares, S. C., Goncalves, L. A., Dorella, F. A., ... Azevedo, V. A. (2016). Whole-genome sequence of Francisella noatunensis subsp. orientalis strain FNO01 isolated from diseased Nile tilapia in Brazil. Genome Announcements, 4(1), e01603-e01615.

Figueiredo, H. C. P., Nobrega Netto, L., Leal, C. A. G., Pereira, U. P., \& Mian, G. F. (2012). Streptococcus iniae outbreaks in Brazilian Nile tilapia (Oreochromis niloticus L.) farms. Brazilian Journal of Microbiology, 43, 576-580.

Fitzsimmons, K. (2015). Tilapia global supply and demand in 2014. Retrieved from http://ag.arizona.edu/azaqua/ista/ markets.htm 
Food and Agriculture Organization of the United Nations. (2016). The state of world fisheries and aquaculture 2016. Contributing to food security and nutrition for all (p. 200). Rome, Italy: FAO.

Geng, Y., Wang, K. Y., Li, C. W., Ren, S. Y., Zhou, Z. Y., Liu, X. X., ... Chen, D. F. (2013). Isolation and characterization of Edwardsiella ictaluri from southern catfish, Silurus soldatovi meridionalis, (Chen) cultured in China. Journal of the World Aquaculture Society, 44, 273-281.

Gong, H. Y., Wu, S. H., Chen, C. Y., Huang, C. W., Lu, J. K., \& Chou, H. Y. (2017). Complete genome sequence of Streptococcus iniae 89353, a virulent strain isolated from diseased tilapia in Taiwan. Genome Announcements, 5(4), e01524-e01516.

Griffin, M. J., Mauel, M. J., Greenway, T. E., Khoo, L. H., \& Wise, D. J. (2011). A real-time polymerase chain reaction assay for quantification of Edwardsiella ictaluri in catfish pond water and genetic homogeneity of diagnostic case isolates from Mississippi. Journal of Aquatic Animal Health, 23, 178-188.

Griffin, M. J., Greenway, T. E., \& Wise, D. J. (2017). Edwardsiella spp. In P. T. K. Woo \& R. C. Cipriano (Eds.), Fish viruses and bacteria: Pathobiology and protection (pp. 9190-9210). Boston, MA: Centre for Agriculture and Bioscience International.

Griffin, M. J., Quiniou, S. M., Cody, T., Tabuchi, M., Ware, C., Cipriano, R. C., ... Soto, E. (2013). Comparative analysis of Edwardsiella isolates from fish in the eastern United States identifies two distinct genetic taxa amongst organisms phenotypically classified as E. tarda. Veterinary Microbiology, 165, 358-372.

Griffin, M. J., Ware, C., Quiniou, S. M., Steadman, J. M., Gaunt, P. S., Khoo, L. H., \& Soto, E. (2014). Edwardsiella piscicida identified in the southeastern USA by gyrB sequence, species specific and repetitive sequence-mediated PCR. Diseases of Aquatic Organisms, 108, 23-35.

Hawke, J., Kent, K., Rogge, M., Baumgartner, W., Wiles, J., Shelley, J., ... Peterson, T. S. (2013). Edwardsiellosis caused by Edwardsiella ictaluri in laboratory populations of Zebrafish Danio rerio. Journal of Aquatic Animal Health, 25, $171-183$.

Hawke, J. P., \& Khoo, L. H. (2004). Infectious diseases. In C. S. Tucker \& J. A. Hargreaves (Eds.), Biology and culture of channel catfish (pp. 387-443). Amsterdam, Netherlands: Elsevier.

Hawke, J. P., McWhorter, A. . C., Steigerwalt, A. G., \& Brenner, D. J. (1981). Edwardsiella ictaluri sp. nov., the causative agent of enteric septicemia of catfish. International Journal of Systematic and Evolutionary Microbiology, 31, 396-400.

Hernandez, E., Figueroa, J., \& Iregui, C. (2009). Streptococcosis on a red tilapia, Oreochromis sp., farm: A case study. Journal of Fish Diseases, 32, 247-252.

Huicab-Pech, Z. G., Landeros-Sánchez, C., Castañeda-Chávez, M. R., Lango-Reynoso, F., \& López-Collado, C. J. (2016). Current state of bacteria pathogenicity and their relationship with host and environment in tilapia Oreochromis niloticus. Journal of Aquaculture Research and Development, 7, 428.

Iregui, C. A., Comas, J., Vasquez, G., \& Verjan, N. (2014). Experimental early pathogenesis of Streptococcus agalactiae infection in red tilapia (Oreochromis spp.). Journal of Fish Diseases, 39, 205-215.

Jantrakajorn, S., Maisak, H., \& Wongtavatchai, J. (2014). Comprehensive investigation of streptococcosis out- breaks in cultured Nile tilapia, Oreochromis niloticus, and red tilapia, Oreochromis sp., of Thailand. Journal of the World Aquaculture Society, 45, 392-402.

Kamaishi, T., Fukuda, Y., Nishiyama, H., Kawakami, H., Ma- tsuyama, T., Yoshinaga, T., \& Oseko, N. (2005). Identification and pathogenicity of intracellular Francisella bacterium in three-lined grunt Parapristipoma trilineatum. Fish Pathology, 40, 67-71.

Keirstead, N. D., Brake, J. W., Griffin, M. J., Halliday-Simmonds, I., Thrall, M. A., \& Soto, E. (2014). Fatal septicemia caused by the zoonotic bacterium Streptococcus iniae during an outbreak in Caribbean reef fish. Veterinary Pathology, 51, 10351041.

Klesius, P. H. (1992). Carrier state of channel catfish infected with Edwardsiella ictaluri. Journal of Aquatic Animal Health, 4 , 227-230.

Krkosek, M. (2010). Host density thresholds and disease control for fisheries and aquaculture. Aquaculture Environment Interactions, 1, 21-32.

Mainardi, R. M., Junior, E. A. L., Junior, J. C. R., Beloti, V., Carmo, A. O., Kalapothakis, E., ... Pereira, U. P. (2016). Complete genome sequence of Streptococcus agalactiae strain S25 isolated from peritoneal liquid of Nile tilapia. Genome Announcements, 4(4), e00784-e00716.

Mohanty, B. R., \& Sahoo, P. K. (2007). Edwardsiellosis in fish: A brief review. Journal of Biosciences, 32, 1331-1344.

Peeler, E. J., \& Taylor, N. (2011). The application of epidemiology in aquatic animal health opportunities and challenges. Veterinary Research, 42, 94.

Phillips, A. C. N., Reichley, S. R., Ware, C., \& Griffin, M. J. (2017). Edwardsiella ictaluri infection in Pangasius catfish imported from West Bengal into the southern Caribbean. Journal of Fish Diseases, 40, 743-756.

Plump, J., \& Hanson, L. (2011). Health maintenance and principal microbial diseases of cultured fishes (3rd ed.). New Delhi, India: Blackwell.

Reichley, S. R., Waldbieser, G. C., Lawrence, M. L., \& Griffin, M. J. (2015). Complete genome sequence of an Edwardsiella piscicida-like species, recovered from tilapia in the United States. Genome Announcements, 3(5), e01004-e01015.

Reichley, S. R., Waldbieser, G. C., Tekedar, H. C., Lawrence, M. L., \& Griffin, M. J. (2015). Complete genome sequence of Edwardsiella tarda isolate FL95-01, recovered from channel catfish. Genome Announcements, 3(3), e00682-e00615.

Reichley, S. R., Waldbieser, G. C., Tekedar, H. C., Lawrence, M. L., \& Griffin, M. J. (2016). Complete genome sequence of Edwardsiella piscicida isolate S11-285 recovered from channel catfish (Ictalurus punctatus) in Mississippi, USA. Genome Announcements, 4(6), e01259-e01216. 
Reichley, S. R., Ware, C., Steadman, J., Gaunt, P. S., García, J. C., LaFrentz, B. R., ... Griffin, M. J. (2017). Comparative phenotypic and genotypic analysis of Edwardsiella isolates from different hosts and geographic origins, with emphasis on isolates formerly classified as E. tarda, and evaluation of diagnostic methods. Journal of Clinical Microbiology, 55, 3466-3491.

Reimschuessel, R., Miller, R. A., \& Gieseker, C. M. (2013). Antimicrobial drug use in aquaculture. In J. F. Prescott, J. D. Baggot, R. D. Walker, \& P. M. Dowling (Eds.), Antimicrobial therapy in veterinary medicine (5th ed., pp. 645-661). San Francisco, CA: Wiley.

Sebastião, F. A., Pilarski, F., Kearney, M. T., \& Soto, E. (2017). Molecular detection of Francisella noatunensis subsp. orientalis in cultured Nile tilapia (Oreochromis niloticus L.) in three Brazilian states. Journal of Fish Diseases, 40, 1731-1735.

Shao, S., Lai, Q., Liu, Q., Wu, H., Xiao, J., Shao, Z., ... Zhang, Y. (2015). Phylogenomics characterization of a highly virulent Edwardsiella strain ET080813T encoding two distinct T3SS and three T6SS gene clusters: Propose a novel species as Edwardsiella anguillarum sp. nov. Systematic and Applied Microbiology, 38, 36-47.

Shoemaker, C. A., Xu, D. H., \& Soto, E. (2017). Streptococcus iniae and S. agalactiae. In P. T. K. Woo \& R. C. Cipriano (Eds.), Fish viruses and bacteria: Pathobiology and protection (pp. 398-313). Boston, MA: Centre for Agriculture and Bioscience International.

Sommerset, I., Krossøy, B., Biering, E., \& Frost, P. (2005). Vaccines for fish in aquaculture. Expert Review of Vaccines, 4 , 89-101.

Soto, E., Griffin, M., Arauz, M., Riofrio, A., Martinez, A., \& Cabrejos, M. E. (2012). Edwardsiella ictaluri as the causative agent of mortality in cultured Nile tilapia. Journal of Aquatic Animal Health, 24, 81-90.

Soto, E., Griffin, M. J., Morales, J. A., Calvo, E. B., de Alexandre Sebastião, F., Porras, A. L., ... Camus, A. C. (2018). Francisella marina sp. nov., Etiologic Agent of Systemic Disease in Cultured Spotted Rose Snapper (Lutjanus guttatus) in Central America. Applied and Environmental Microbiology, 84.

Soto, E., Hawke, J. P., Fernandez, D., \& Morales, J. A. (2009). Francisella sp., an emerging pathogen of tilapia, Oreochromis niloticus (L.), in Costa Rica. Journal of Fish Diseases, 32, 713-722.

Soto, E., Kidd, S., Mendez, S., Marancik, D., Revan, F., Hiltchie, D., \& Camus, A. (2013). Francisella noatunensis subsp. orientalis pathogenesis analyzed by experimental immersion challenge in Nile tilapia, Oreochromis niloticus (L.). Veterinary Microbiology, 164, 77-84.

Soto, E., McGovern-Hopkins, K., Klinger-Bowen, R., Fox, B. K., Brock, J., Antonio, N., ... Tamaru, C. S. (2013). Prevalence of Francisella noatunensis subsp. orientalis in cultured tilapia on the Island of Oahu, Hawaii. Journal of Aquatic Animal Health, 25, 104-109.

Soto, E., Primus, A. E., Pouder, D. B., George, R. H., Gerlach, T. J., Cassle, S. E., ... Yanong, R. P. (2014). Identification of Francisella noatunensis in novel host species French grunt (Haemulon flavolineatum) and Caesar grunt (Haemulon carbonarium). Journal of Zoo and Wildlife Medicine, 45, 727-731.

Soto, E., Richey, C., Stevens, B., Yun, S., Kenelty, K., Reichley, S., ... Camus, A. (2017). Co-infection of Acipenserid herpesvirus 2 (AciHV-2) and Streptococcus iniae in cultured white sturgeon Acipenser transmontanus. Diseases of Aquatic Organisms, 124, 11-20.

Soto, E., Wang, R., Wiles, J., Baumgartner, W., Green, C., Plumb, J., \& Hawke, J. (2015). Characterization of Isolates of Streptococcus agalactiae from Diseased Farmed and Wild Marine Fish from the U.S. Gulf Coast, Latin America, and Thailand. Journal of Aquatic Animal Health, 27, 123-234.

Soto, E., Zayas, M., Tobar, J., Illanes, O., Yount, S., Francis, S., \& Dennis, M. M. (2016). Laboratory-controlled Challenges of Nile Tilapia (Oreochromis niloticus) with Streptococcus agalactiae: Comparisons between Immersion, Oral, Intracoelomic and Intramuscular Routes of Infection. Journal of Comparative Pathology, 155, 339-345.

Webster, C., \& Lim, C. (2006). Tilapia: Biology, culture, and nutrition. New York, NY: CRC Press.

Wise, D. J., Camus, A. C., Schwedler, T. E., \& Terhune, J. S. (2004). 15 health management. Developments in Aquaculture and Fisheries Science, 34, 444-503.

Yamada, Y., \& Wakabayashi, H. (1999). Identification of fish-pathogenic strains belonging to the genus Edwardsiella by sequenceanalysis of sodB. Fish Pathology, 34, 145-150.

Ye, S., Li, H., Qiao, G., \& Li, Z. (2009). First case of Edwardsiella ictaluri infection in China farmed yellow catfish Pelteobagrus fulvidraco. Aquaculture, 292, 6-10.

How to cite this article: López-Porras A, Elizondo C, Chaves AJ, et al. Application of multiplex quantitative Polymerase chain reaction methods to detect common bacterial fish pathogens in Nile tilapia, Oreochromis niloticus, hatcheries in Costa Rica. J World Aquacult Soc. 2018;1-14. https://doi.org/10.1111/jwas.12576 